Univerzitet u Beogradu
Poljoprivredni fakultet
Institut za poljoprivrednu tehniku
Naučni časopis
POLJOPRIVREDNA TEHNIKA
Godina XLIII
Broj 2, 2018.
Strane: $36-45$

\title{
SAFE DRIVING AND WORKING WITH AGRICULTURAL AND FORESTRY VEHICLES IN THE REPUBLIC OF SLOVENIA
}

\author{
Robert Jerončič ${ }^{*}$ \\ ${ }^{1}$ Ministry of Infrastructure, Langusova ulica 4, Ljubljana, Slovenia
}

\begin{abstract}
If we want to reduce the number of fatalities and injured people because of driving and working with agricultural and forestry vehicles, we have to regulate the whole area of use such vehicles. First step for this are conformity assessment procedures before putting agricultural and forestry vehicles on the market to achieve that only approved vehicles will come to the market. At the moment of the registration procedure of these vehicles for the use on public roads and for work these vehicles have to be equipped with the equipment that is obliged and prescribed in the EU harmonised legislation and in the national legislation. In the exploitation these vehicles have to be in good condition that is checked with the periodic roadworthiness tests. This area is well regulated and harmonised because it is prescribed in the EU legislation. And finally the police and different inspectorates perform the roadside inspections that check the technical condition of these vehicles at driving and also at work on the field. On the other side also the drivers of agricultural and forestry vehicles need education in order to recognise what is the proper use of these vehicles, where their limits are and how to recognise the moments where they are only one step from causing an accident. If all mentioned systems work properly there is a possibility to reduce the number of fatalities and injured people with such vehicles.
\end{abstract}

Key words: safety, legislation, agricultural vehicles, forestry vehicles, approval

\section{INTRODUCTION}

Human lives are the most valuable and for this reason we have to protect people in all areas of work and living. One of these areas are also save driving and working with agricultural and forestry vehicles. Working and driving with these vehicles is regulated in all areas.

\footnotetext{
* Corresponding author: robert.jeroncic@gov.si
} 
Namely, there is a conformity assessment legislation that regulate agricultural and forestry vehicles before they are send to the market, then we have legislation about the equipment of those vehicles, legislation for yearly roadworthiness tests, some of those vehicles could be a subject of roadside inspection and there is also a legislation that define the supervision of this field.
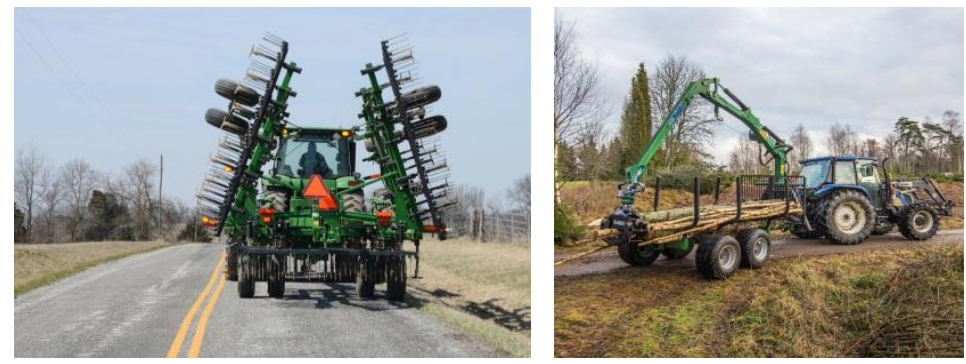

Figure 1. Agricultural and forestery tractors on public road, [19].

\section{CONFORMITY ASSESMENT OF AGRICULTURAL AND FORESTRY VEHICLES}

The first step is the legislation on conformity assessment of agricultural and forestry vehicles (Fig.1.) that are prepared by experts and various working groups from this field and approved by institutions in Brussels.

In Brussels, regulations with the approval content are published, that are obligatory acts for all European Union Member States. For the type approval a framework Regulation is Regulation (EU) No 167/2013 of the European Parliament and of the Council of 5 February 2013 on the approval and market surveillance of agricultural and forestry vehicles [1]. Other parts, components and systems are regulated with the following acts:

- Commission Delegated Regulation (EU) No 1322/2014 of 19 September 2014 supplementing and amending Regulation (EU) No 167/2013 of the European Parliament and of the Council with regard to vehicle construction and general requirements for the approval of agricultural and forestry vehicles [2],

- Commission Delegated Regulation (EU) 2015/68 of 15 October 2014 supplementing Regulation (EU) No 167/2013 of the European Parliament and of the Council with regard to vehicle braking requirements for the approval of agricultural and forestry vehicles [3],

- Commission Delegated Regulation (EU) 2015/96 of 1 October 2014 supplementing Regulation (EU) No 167/2013 of the European Parliament and of the Council as regards environmental and propulsion unit performance requirements of agricultural and forestry vehicles [4],

- Commission Delegated Regulation (EU) 2015/208 of 8 December 2014 supplementing Regulation (EU) No 167/2013 of the European Parliament and of the Council with regard to vehicle functional safety requirements for the approval of agricultural and forestry vehicles [5],

- Commission Implementing Regulation (EU) 2015/504 of 11 March 2015 implementing Regulation (EU) No 167/2013 of the European Parliament and of the 
Council with regard to the administrative requirements for the approval and market surveillance of agricultural and forestry vehicles [6].

Beside this in Geneva in the working group World Forum for Harmonization of Vehicle Regulations (WP.29) within the United Nations Economic Commission for Europe (UNECE) various UNECE Regulations are published, but the contracting parties to the UNECE Agreement could decide whether they will use this legislation or not. If we mentioned some of them, that are relevant also for agricultural and forestry vehicles:

- UNECE Regulation No. 14 [7],

- UNECE Regulation No. 16 [8],

- UNECE Regulation No. 43 [9],

- UNECE Regulation No. 60 [10] ...

In this field there are also OECD Codes that are prepared in Paris within the Organisation for Economic Co-operation and Development (OECD). For agricultural and forestry vehicles are relevant the following Codes:

- OECD Code 3: OECD standard code for the testing of the strength of protective structures for agricultural and forestry tractors (dynamic test),

- OECD Code 4: OECD standard code for the testing of the strength of protective structures for agricultural and forestry tractors (static test),

- OECD Code 5: OECD standard code for the official measurement of noise at the driving position(s) on agricultural and forestry tractors,

- OECD Code 6: OECD standard code for the testing of front-mounted protective structures on narrow-track wheeled agricultural and forestry tractors,

- OECD Code 7: OECD standard code for the testing of the rear-mounted protective structures on narrow-track wheeled agricultural and forestry tractors,

- OECD Code 8: OECD standard code for the official testing of protective structures on agricultural and forestry tracklaying tractors,

- OECD Code 9: OECD standard code for the official testing of protective structures for telehandlers,

- OECD Code 10: OECD standard code for the official testing of falling object protective structures on agricultural and forestry tractors.

All this legislation is very important for the producers of agricultural and forestry vehicles because their products have to fulfil all the requirements from the legislation if they want to put these products for sale on the market. And on the other side all the technical services or laboratories for approval tests have to be very familiar with this legislation to perform test on a proper way.

This is the first step to safe working and driving. The next step is to organize safety at working and driving on roads.

\section{EQUIPMENT OF AGRICULTURAL AND FORESTRY VEHICLES}

\subsection{Obligatory equipment}

In the Republic of Slovenia, the equipment of all road vehicles is prescribed in the Rules on parts and equipment of vehicles [7] where all parts of vehicles and their equipment that is not included in harmonised legislation are prescribed. This area is not harmonised within the European Union yet but we in the Republic of Slovenia have similar prescriptions as other European Union Member States. 
The equipment is divided into two groups, obligatory and mandatory equipment. For agriculture and forestry vehicles it is prescribed, that those vehicles have to be equipped with:

- $\quad$ safety triangle type approved according to the UNECE Regulation No.27 [8],

- box with first aid material,

- chocks to prevent vehicles from moving.

If the design speed of agriculture and forestry vehicles is not higher than $40 \mathrm{~km} / \mathrm{h}$ they have to be on the back side marked with the rear marking plates for slow-moving vehicles type approved according to the UNECE Regulation No. 69 [9]. Mandatory equipment of agriculture and forestry vehicles are additional working lamps that helps the driver to work also at night or in conditions of reduced visibility.

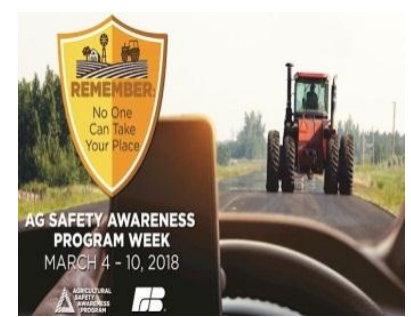

Figure 2. Some lables on th

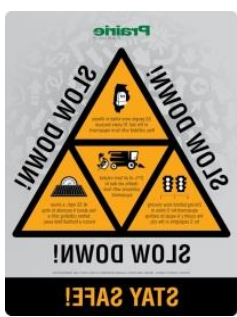

or forestery machines, [18].

For a better traffic safety, we prescribed for agriculture and forestry vehicles similar retro reflexive elements like in some other European union member states (Fig.2). Namely, agricultural and forestry tractors and their trailers or tractor attachments and working machines with a width of more than 2,55 m must have in road traffic at the far points of their width front and rear transversally fitted warning signs according to the SIST EN 12899-1 standard DIN, class RA 2, CR 2. The tables must be at least $400 \mathrm{~mm} x$ $400 \mathrm{~mm}$ in size and $100 \mathrm{~mm}$ wide reflective white and red belts must be exchanged at an angle of $45^{\circ}$ (Fig.3.) . If the design of the vehicle so permits, labels with the same characteristics as the warning signs may be affixed instead of the tables.
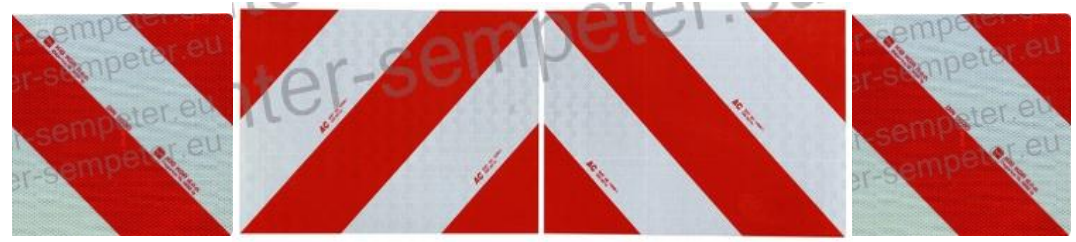

Figure 3. Reflective tables standard DIN, class RA 2, CR 2 for agriculture and forestery vehicles in Slovenia public traffic [18], [20].

If the design of the vehicle does not allow the fitting of marking tables of the prescribed size, marking plates or marking labels of the same characteristics may be installed, with a minimum area of $600 \mathrm{~cm}^{2}$ and a smallest side of $120 \mathrm{~mm}$. 
If the distance between the outer edge of agriculture and forestry vehicles or tractor connections and the outer edge of the vehicle's position lamps is more than $400 \mathrm{~mm}$, at night or in conditions of reduced visibility, as close as possible to the outer edge, additional position lamps and retro-reflectors back and forth.

The outer edges of the tractor attachments not exceeding 2,55 m may be marked with the signboards or labels, but having up to 2,0 m are fitted with components which may be dangerous to others participants in traffic and are not easily visible (e.g. blades, tips, spokes, edges).

All vehicles that operate at $40 \mathrm{~km} / \mathrm{h}$ or less, including: tractors, self-propelled agricultural and forestery equipment, road construction \& maintenance machinery, animal-powered vehicles. Slow-moving vehicle sign , standard HTA 76
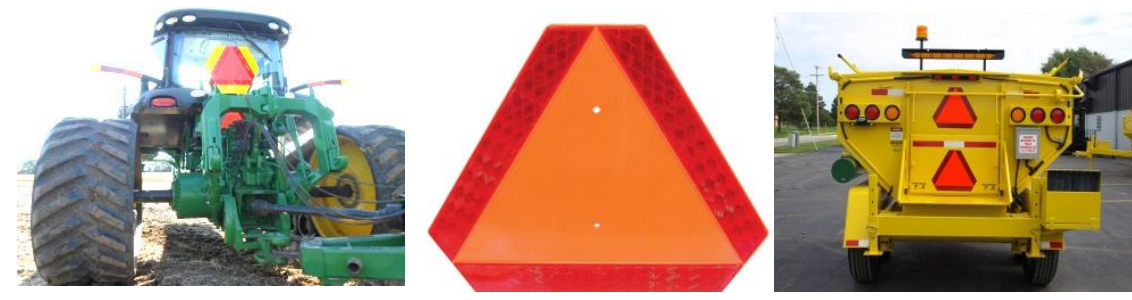

Figure 4. Slow Mowing Vehicle (SMV) sign for agriculture and forestery vehicles in Slovenia public traffic [18], [20].

The sign SMV (EU regulation ECE R No 69.01: Max. length $30.6 \mathrm{~cm}$, height 35 $\mathrm{cm}$, and red retro-reflective border $4.5 \mathrm{~cm}$ ), anshould be placed as close as practical to the centre of the rear of the vehicle and between $0.6 \mathrm{~m}$ and $2 \mathrm{~m}$ above the road: It must be clearly visible for a distance of not less than $150 \mathrm{~m}$

The regulation sets out the minimum dimensions, shape, colour and reflectivity of the sign SMV.

The sign SMV may be larger provided each dimension is increased by the same amount. A sign SMV should be replaced when faded or damaged.

\section{PERIODICAL ROADWORTHINESS TESTS OF AGRICULTURAL AND FORESTRY VEHICLES}

\subsection{Legal basis}

Prescriptions for periodical roadworthiness tests of the road vehicles are harmonised in the European Union. This area is already for a long time prescribed with the EU Directives. The last Directive for this area comes into force in May 2017. This is Directive 2014/45/EU of the European Parliament and of the Council of 3 April 2014 on periodic roadworthiness tests for motor vehicles and their trailers and repealing Directive 2009/40/EC [10]. 


\subsection{Slovene legislation}

In the Republic of Slovenia, we transpose the content of the Directive mentioned in 3.1 for practical reasons into three acts. Some prescriptions have been inserted into the Motor Vehicle Act [5] especially the articles on the scope that prescribe which categories of vehicles have to go to the periodic roadworthiness tests, frequency of inspections and penalties. According to this Directive periodic roadworthiness tests are obligatory only for tractors of category T5 (wheeled tractors with a maximum design speed of more than $40 \mathrm{~km} / \mathrm{h}$ ) but we have prescribed from the beginning that all agriculture and forestry tractors have to be inspected.

Detail prescriptions regarding the periodic roadworthiness tests procedures and for the equipment needed for these test are transposed into the Ministerial Rules on technical inspections for motor vehicles and their trailers.

Directive 2014/45/EU described in Annex I very detailed prescriptions which parts and systems of vehicles have to inspected, the way of inspection and possible deficiencies. The deficiencies have to be classified into three groups, minor, major and dangerous. Minor deficiencies have no significant effect on the safety of the vehicle and the vehicle could be in the traffic.

Major deficiencies may prejudice the safety of the vehicle of have an impact on the environment or put other road users at risk and therefore the driver has to repair the vehicle and come back to the technical inspection. If the vehicle has dangerous deficiencies, such vehicle constituting a direct and immediate risk to road safety or an impact to the environment and such vehicle is not allowed in the traffic unless it is repaired. This Annex is transposed into Slovene national legislation through the technical specification on procedures for periodic roadworthiness tests No. TSV 605 [11].

According to the legislation mentioned above agriculture and forestry tractors of all categories have to be inspected periodically. In the Republic of Slovenia all new tractors have to be inspected first time after 4 years, then twice after two years and later every year. This periodic is the same as for passenger cars.

At the moment in the Republic of Slovenia there are about 100 authorised organisations for periodic roadworthiness tests. Authorisation is given by the Slovene Road Traffic Safety Agency which also act as an approval authority. These organisations are quite evenly distributed in Slovenia but because of the specific use of such vehicles there is a possibility prescribed in the Ministerial Rules that those authorised organisations for periodic roadworthiness tests could perform tests on every town or village where appropriate flat and smooth surface is available.

\section{ROADSIDE INSPECTIONS OF AGRICULTURAL AND FORESTRY VEHICLES}

\subsection{Legal basis}

Prescriptions for roadside inspections of the road vehicles are also harmonised in the European Union. This area is already for a long time prescribed with the EU Directives. The last Directive for this area comes into force in May 2017. 
This is Directive 2014/47/EU of the European Parliament and of the Council of 3 April 2014 on the technical roadside inspection of the roadworthiness of commercial vehicles circulating in the Union and repealing Directive 2000/30/EC [12].

Prescriptions covered only commercial vehicle and this Directive included also agricultural and forestry vehicles of category T5. According to the European Commission wheeled tractors with a maximum design speed exceeding $40 \mathrm{~km} / \mathrm{h}$ are increasingly used to replace trucks in local transport activities and for commercial road haulage purposes. Their risk potential is comparable to that of trucks, and vehicles in that category, which are used mainly on public roads, should therefore be treated in the same way as trucks when it comes to technical roadside inspections.

\subsection{Slovene legislation}

In the Republic of Slovenia, the Directive from 4.1 has been transposed with the Motor vehicle act and, the major part, with the Ministerial Order on roadside inspections of the road vehicles [13]. Competent authorities are Police and Inspectorate of the Republic of Slovenia for Infrastructure. According to the regulation they perform the initial roadside technical inspections and detailed roadside technical inspections.

In most cases for detailed roadside inspections the use authorised organisations for periodic roadworthiness tests who perform extraordinary roadworthiness test. For such tests prescriptions and procedures are the same as for ordinary roadworthiness test and are listed in the technical specification on procedures for periodic roadworthiness tests No. TSV 605

\section{THE SUPERVISION OF AGRICULTURAL AND FORESTRY VEHICLES}

\subsection{Slovene legislation}

In the Republic of Slovenia, the supervision on use and work with agriculture and forestry tractors are prescribed by the Motor Vehicle Act. According to this act the competent authorities are Police, Inspectorate of the Republic of Slovenia for Infrastructure, Inspectorate of the Republic of Slovenia for Agriculture, Forestry, Hunting and Fisheries and Labour Inspectorate of the Republic of Slovenia. The Labour Inspectorate of the Republic of Slovenia supervise only by legal and natural persons who have the status of an employer or a self-employed person, in accordance with the regulations governing occupational safety and health. The supervision of tractors at agricultural and forestry work outside the roads only covers safety elements on tractors.

\section{CONCLUSIONS}

All the above-mentioned measures for higher safety apply only to agricultural and forestry vehicles. We must be aware, however, that this is only part of the security field. If we want to ensure thorough and deliberate safety, it is necessary to ensure that the drivers of these tractors are well trained. If drivers do not recognize dangerous situations and react correctly in such situations, an accident and casualty may occur despite a safe vehicle. 


\section{REFERENCES}

[1] Regulation (EU) No 167/2013 of the European Parliament and of the Council of 5 February 2013 on the approval and market surveillance of agricultural and forestry vehicles, Official Journal of the European Union, No. 60, 2 March 2013, pp. 1-49.

[2] Commission Delegated Regulation (EU) No 1322/2014 of 19 September 2014 supplementing and amending Regulation (EU) No 167/2013 of the European Parliament and of the Council with regard to vehicle construction and general requirements for the approval of agricultural and forestry vehicles, Official Journal of the European Union, No. 364, 18 December 2014, pp. 1-315.

[3] Commission Delegated Regulation (EU) 2015/68 of 15 October 2014 supplementing Regulation (EU) No 167/2013 of the European Parliament and of the Council with regard to vehicle braking requirements for the approval of agricultural and forestry vehicles, Official Journal of the European Union, No. 17, 23 January 2015, pp. 1-139.

[4] Commission Delegated Regulation (EU) 2015/96 of 1 October 2014 supplementing Regulation (EU) No 167/2013 of the European Parliament and of the Council as regards environmental and propulsion unit performance requirements of agricultural and forestry vehicles, Official Journal of the European Union, No. 16, 23 January 2015, pp. 1-21.

[5] Commission Delegated Regulation (EU) 2015/208 of 8 December 2014 supplementing Regulation (EU) No 167/2013 of the European Parliament and of the Council with regard to vehicle functional safety requirements for the approval of agricultural and forestry vehicles, Official Journal of the European Union, No. 42, 17 February 2015, pp. 1-175.

[6] Commission Implementing Regulation (EU) 2015/504 of 11 March 2015 implementing Regulation (EU) No 167/2013 of the European Parliament and of the Council with regard to the administrative requirements for the approval and market surveillance of agricultural and forestry vehicles, Official Journal of the European Union, No. 85, 28 March 2015, pp. 1-197.

[7] UNECE Regulation No. 14, Uniform provisions concerning the approval of vehicles with regard to safety-belt anchorages, ISOFIX anchorages systems and ISOFIX top tether anchorages and i-Size seating positions.

[8] UNECE Regulation No. 16, Uniform provisions concerning the approval of:

I. Safety-belts, restraint systems, child restraint systems and ISOFIX child restraint systems for occupants of power-driven vehicles

II. Vehicles equipped with safety-belts, safety-belt reminders, restraint systems, child restraint systems and ISOFIX child restraint systems and i-Size child restraint systems.

[9] UNECE Regulation No. 43, Uniform provisions concerning the approval of safety glazing materials and their installation on vehicles.

[10] UNECE Regulation No. 60, Uniform provisions concerning the approval of two-wheeled motor cycles and mopeds with regard to driver-operated controls including the identification of controls, tell-tales and indicators.

[11] Pravilnik o delih in opremi vozil ("Rules on parts and equipment of vehicles"), Uradni list RS, No. 44/14, 36/14, 69/15, 44/17 and 75/17.

[12] UNECE Regulation No. 27, Uniform provisions concerning the approval of advance-warning triangles.

[13] UNECE Regulation No. 69, Uniform provisions concerning the approval of rear marking plates for slow-moving vehicles (by construction) and their trailers. 
[14] Directive 2014/45/EU of the European Parliament and of the Council of 3 April 2014 on periodic road worthiness tests for motor vehicles and their trailers and repealing Directive 2009/40/EC (OJ L 127, 29.4.2014, p. 51-128).

[15] Motor Vehicle Act (OJ RS, No. 75/17).

[16] Odredba o določitvi seznama tehničnih specifikacij o postopkih s področja motornih in priklopnih vozil ("Ministerial Order on setting a list of technical specifications on procedures for motor vehicles and their trailers") Uradni list RS, št. 50/11, 106/11, 72/14, 9/17 and 75/17 - ZMV-1 and Tehnična specifikacija za vozila št. TSV 605/02 o postopkih za izvedbo tehničnih pregledov motornih in priklopnih vozil ("Technical specification for vehicles No. $605 / 02$ on procedures for periodic roadworthiness tests for motor vehicles and their trailers").

[17] Directive 2014/47/EU of the European Parliament and of the Council of 3 April 2014 on the technical roadside inspection of the roadworthiness of commercial vehicles circulating in the Union and repealing Directive 2000/30/EC (OJ L 127, 29.4.2014, p. 134-218).

[18] http://tabletop.texasfarmbureau.org/2017/07/drive-slow-save-life/

[19] https://www.modhoster.com/mods/wellcome-to-slovenia-17

[20] http://www.mto.gov.on.ca/english/trucks/pdfs/farm-guide-farm-equipment-on-thehighway.pdf

\title{
SIGURNA VOŽNJA I RADOVI SA POLJOPRIVREDNIM I ŠUMSKIM VOZILIMA U REPUBLICI SLOVENIJI
}

\author{
Robert Jerončičć ${ }^{* 1}$ \\ ${ }^{1}$ Ministry of Infrastructure, Langusova ulica 4, Ljubljana, Slovenia ${ }^{2}$
}

Sažetak: Ako želimo da smanjimo broj smrtnih slučajeva i povređenih ljudi zbog vožnje i rada sa poljoprivrednim i šumskim vozilima, moramo regulisati čitavu oblast korišćenja takvih vozila. Prvi korak za to su procedure za ocenjivanje usaglašenosti pre nego što se na tržištu pojave neka poljoprivredna i šumska vozila. Tako se postigne da na tržište dođu samo odobrena po Zakonu ispravna pomenuta vozila.

U momentu postupka registracije ovih vozila za upotrebu na javnim putevima i za rad ova vozila moraju imati opremomu koja je obavezna i propisana u zakonodavstvu EU i nacionalnom zakonodavstvu (Slovenija). U eksploataciji ova vozila moraju biti u dobrom stanju koje se proverava periodičnim testovima tehničkog pregleda. Ova oblast je dobro regulisana i usklađena jer je propisana u zakonodavstvu EU. Na kraju, policija i različiti inspektori obavljaju inspekciju na putevima koji proveravaju tehničko stanje ovih vozila prilikom vožnje na javnim i drugim puteviam i na radnom mestu. Sa druge strane, vozači poljoprivrednih i sumskih vozila moraju imati obrazovanje kako bi prepoznali pravilnu upotreba ovih vozila, gde su njihove granice i kako prepoznati trenutke u kojima su samo jedan korak od uzroka nesreće. Ako svi pomenuti sistemi ispravno funkcionišu, postoji mogućnost smanjenja broja smrtnih slučajeva i povrieđenih osoba koje rade sa takvim vozilima.

Ključne reči: Bezbednost, zakonodavstvo, poljoprivredna vozila, šumska vozila

\footnotetext{
* robert.jeroncic@gov.si
} 
Prijavljen: Submitted:

Ispravljen:

Revised:

Prihvaćen:

Accepted:

24.03.2018.

25.05.2018

16.07.2018. 